\title{
PENGENALAN KONSEP PANGIDER BHUANA KE DALAM PELATIHAN KARAWITAN BALI
}

\author{
Oleh : \\ I Nyoman Mariyana1, Gek Diah Desi Sentana² \\ ${ }^{1}$ Sekolah Menengah Atas Negeri 8 Denpasar \\ ${ }^{2}$ Dosen Institut Hindu Dharma Negeri Denpasar \\ ${ }^{1}$ nyomanmariyana@gmail.com, ${ }^{2}$ gekdiahdesisentana@gmail.com
}

\begin{abstract}
Abstrak
The realization of a work of art takes place through a process that takes place starting from the impulse felt by an artist to make his work until the work becomes a reality. The process can run easily and quickly, but it can also take a very long time, instead it can stop in the middle of the road, until the work that is forced never materializes. The process of cultivating works of art, includes three important stages that must be passed. The three stages used in the cultivation process to realize this artwork are: exploration (exploration), experimental (Improvisation) and formation (Forming) stages. In the Lontar Prakempa, a Balinese gamelan mythology which is thought to be quite old, contains ins and outs of Balinese gamelan which essentially contains tatwa (philosophy or logic), morality (ethics), longo (aesthetics) and gegebug (technique) which are in harmony with Balinese gamelan. In the lontar also explained about the concept of Pangider Bhuana as a symbol of the ruler of the universe. In the Lontar Prakempa, a Balinese gamelan mythology which is thought to be quite old, contains ins and outs of Balinese gamelan which essentially contains tatwa (philosophy or logic), morality (ethics), longo (aesthetics) and gegebug (technique) which are in harmony with Balinese gamelan. In the lontar also explained about the concept of Pangider Bhuana as a symbol of the ruler of the universe.
\end{abstract}

\section{Keyword: introduction, concept, pengider bhuana, karawitan}

\section{PENDAHULUAN}

Pada dasarnaya proses perwujudan karya seni itu menyangkut dua tahap : yang pertama adalah penciptaannya yang mulai dengan dorongan yang dirasakan, yang disusul dengan ilham yang menemukan cara-cara untuk perwujudannyan, dan yang kedua adalah pekerjaan perwujudannya sampai karya itu selesai (Djelantik. 1987 : 38). Setiap tahap pada proses ini dan hasil pekerjaan sang seniman selalu akan mengandung ciri-ciri khas yang merupakan akibat dari segala pengaruh dan pengalaman-pengalaman sang seniman baik yang sadar maupaun yang tak sadar. Pengaruh-pengaruh tersebut berkaitan dengan lingkungan hidupnya, dengan pendidikannya, dengan apa yang pernah dibaca, dengan pengalaman yang khusus dan latar belakang kebudayaan (Djelantik. 1987 : 39).

Begitu juga dengan penemuan ide sampai pada terbentuknya sebuah komposisi Karawitan. Di dalam penggarapan sebuah bentuk komposisi, para seniman berkreativitas untuk menghasilkan sesuatu yang baru mengenai pembaharuan konsepkonsep estetikannya, teknik, falsafah/makna dan fungsi. Segala yang terjadi dalam sebuah komposisi mengalami proses. Proses tersebut tidak saja berjalan dengan mulus tetapi kadang-kadang terjadi hambatan yang tidak akan pernah terduga sebelumnya.

Proses penggarapan karya seni, meliputi tiga tahap penting yang harus dilalui. Adapun ketiga tahapan yang dipakai dalam proses penggarapan untuk mewujudkan karya seni ini adalah : tahap penjajagan (Ekplorasi), 
tahap percobaan (Improvisasi) dan tahap pembentukan (Forming) (Alma M. Hawkins. $1990: 27-48)$.

\section{Tahap penjajagan (Ekplorasi)}

Eksplorasi termasuk berpikir, berimajinasi, merasakan dan merespon segala sesuatu yang timbul dari pikiran. Segala sesuatu yang dimbul dari imajinasi merupakan rancangan awal dari apa-apa yang telah terpikirkan. Tetapi kadang-kadang pikiran dan pengalaman yang dirasakan merupakan sesuatu yang dapat memotifasi seseorang untuk mencipta sesuatu yang didukung dengan mencari referensi-referensi yang relevan dengan karya

\section{Tahap Percobaaan (Improvisasi)}

Improvisasi memberikan kesempatan yang lebih besar bagi imajinasi, seleksi dan mencipta dari pada eksplorasi karena dalam improvisasi terdapat kebebasan yang lebih, maka jumlah keterlibatan diri dapat ditingkatkan. Dalam proses ini penyediaan dorongan motivasi, menyebabkan diri merespon dan membuat tindakan yang lebih dalam artinya merespon segala sesuatu yang timbul dari proses eksplorasi.

Pada tahap ini, telah mulai dicatat beberapa motif lagu yang akan dituangkan dalam garapan/karya. Pada tahap ini pula, telah dideskripsikan bagian-perbagian dari konsep yang telah dibuat dalam bentuk notasi. Segala sesuatu yang berhubungan dengan penciptaan karya seni tidak luput dari perubahan yang terjadi dalam proses penggarapannya.

\section{Tahap Pembentukan (Forming)}

Tahap ini merupakan tahap yang sangat menentukan terwujudnya sebuah garapan karya seni. Pada tahap ini proses penuangan dari apa yang diungkapkan lewat tulisan mulai ditranspormasikan lewat media garap. Penuangan ide yang sebelumnya ditulis diatas kertas, digarap kedalam bentuk komposisi musik sesuai dengan konsep si penggarap sampai karya tersebut terbentuk.

\section{PEMBAHASAN}

1. Penanaman Konsep Pangider Bhuana melalui pelatihan Karawitan Balisalah satu inspirasi seniman dalam berkarya menciptakan komposisi Karawitan

Sesungguhnya Hindu sangat kaya dengan konsep-konsep agama yang mengatur tentang tatanan umatnya. Mulai dari konsep Tri Hita Karana, yakni sebuah konsep yang meyakini adanya hubungan manusia dengan Tuhan, (Parhyangan), hubungan manusia dengan manusia (Pawongan), hubungan manusia dengan lingkungan (Palemahan), konsep Tri Rna yaitu : sebuah konsepsi tentang hutang secara moral : kehadapan para Dewa (Dewa Rna), para leluhur (Pitra Rna), dan para Rsi (Rsi Rna), sampai pada konsep Pangider Bhuana yaitu Peranan dan simbol Dewata Nawa Sanga dalam segala penjuru arah mata angin yang menjadi kekuatan penegteg jagat atau kestabilan Bhuana Agung (alam Semesta) dan Bhuana Alit (manusia).

Didalam lontar Prakempa yaitu sebuah lontar mitologi gamelan Bali yang diduga cukup tua umurnya, memuat seluk beluk gamelan Bali yang pada hakekatnya beritikan tatwa (filsafat atau logika), susila (etika), longo (estetika) dan gegebug (teknik) yang bertalikan dengan gamelan Bali. Dalam lontar tersebut juga dijelaskan tentang konsep Pangider Bhuana sebagai simbol penguasa alam semesta. Seperti di bawah ini.

\begin{tabular}{|l|l|l|l|}
\hline Arah & Timur/ purwa & Arah & Tenggara/ Ghnenya \\
\hline Urip & 5 & Urip & 8 \\
\hline Pura & Lempuyang & Pura & Goa lawah \\
\hline Dewa & Iswara & Dewa & Maheswara \\
\hline Aksara & Sa ; Pranawa" & Aksara & Na, "Nang" \\
Suci & Mang" & Suci & \\
\hline Fungsi & Pralina/pelebur & Fungsi & Keseimbangan natural \\
\hline Warna & Putih & Warna & Merah muda \\
\hline Wahana & & Wahana & Merak \\
\hline
\end{tabular}


GUNA WIDYA : JURNAL PENDIDIKAN HINDU JURUSAN PENDIDIKAN AGAMA

FAKULTAS DHARMA ACARYA INSTITUT HINDU DHARMA NEGERI DENPASAR
VOLUME 6 NOMOR 1 MARET 2019

ISSN : 2355-5696 (CETAK)

ISSN : 2655-0156 (ONLINE)

http://ejournal.ihdn.ac.id/index.php/GW

\begin{tabular}{|l|l|l|l|}
\hline Senjata & Bajra/genta & Senjata & Dupa \\
\hline Panca & Umanis & Panca & \\
Wara & & Wara & \\
\hline Sapta & Redite & Sapta & Wrhaspati \\
Wara & & Wara & \\
\hline Sakti & Dewi uma & Sakti & Dewi laksi \\
\hline Nada & Dang (ksang) & Nada & Ndang (hrang) \\
\hline
\end{tabular}

\begin{tabular}{|c|c|c|c|}
\hline Arah & Selatan/ Daksina & Arah & Barat Daya/Nairiti \\
\hline Urip & 9 & Urip & 3 \\
\hline Pura & Andakasa & Pura & Uluwatu \\
\hline Dewa & Brahma & Dewa & Rudra \\
\hline $\begin{array}{l}\text { Aksara } \\
\text { Suci }\end{array}$ & $\begin{array}{l}\text { Ba;Bang; Pranawa } \\
\text { Ang }\end{array}$ & $\begin{array}{l}\text { Aksara } \\
\text { Suci }\end{array}$ & Ma, "Mang" \\
\hline Fungsi & Pencipta (utpati) & Fungsi & Pemancar Tri Murti \\
\hline Warna & Merah & Warna & Jingga \\
\hline Wahana & Angsa & Wahana & Kerbau Putih \\
\hline Senjata & Gada & Senjata & Moksala \\
\hline $\begin{array}{l}\text { Panca } \\
\text { Wara }\end{array}$ & Paing & $\begin{array}{l}\text { Panca } \\
\text { Wara }\end{array}$ & \\
\hline $\begin{array}{l}\text { Sapta } \\
\text { Wara }\end{array}$ & Saniscara & $\begin{array}{l}\text { Sapta } \\
\text { Wara }\end{array}$ & Anggara \\
\hline Sakti & Dewi Saraswati & Sakti & Dewi Sumadhi \\
\hline Nada & Ding (ksing) & Nada & Nding (hring) \\
\hline Arah & Barat/Pascima & Arah & Barat Laut \\
\hline Urip & 7 & Urip & 1 \\
\hline Pura & Batukaru & Pura & Puncak Mangu \\
\hline Dewa & Mahadewa & Dewa & Sangkara \\
\hline $\begin{array}{l}\text { Aksara } \\
\text { Suci }\end{array}$ & $\mathrm{Ta}$ & $\begin{array}{l}\text { Aksara } \\
\text { Suci }\end{array}$ & $\mathrm{Si}($ Sing) \\
\hline Fungsi & $\begin{array}{l}\text { Sumber kekuatan } \\
\text { intuisi }\end{array}$ & Fungsi & Pengembangan Tanaman \\
\hline Warna & Kuning & Warna & Hijau/welis \\
\hline Wahana & Naga & Wahana & Singa \\
\hline Senjata & Naga Pasa & Senjata & Angkus \\
\hline $\begin{array}{l}\text { Panca } \\
\text { Wara }\end{array}$ & Pon & $\begin{array}{l}\text { Panca } \\
\text { Wara }\end{array}$ & \\
\hline $\begin{array}{l}\text { Sapta } \\
\text { Wara }\end{array}$ & Buda & $\begin{array}{l}\text { Sapta } \\
\text { Wara }\end{array}$ & Sukra \\
\hline Sakti & Dewi Sanci & Sakti & Dewi Rodri \\
\hline Nada & Deng (kseng) & Nada & Ndeng (hreng) \\
\hline
\end{tabular}

\begin{tabular}{|l|l|l|l|}
\hline Arah & Utara/ Uttara & Arah & Timur Laut \\
\hline Urip & 4 & Urip & 6 \\
\hline Pura & Batur & Pura & Pengubengan \\
\hline Dewa & Wisnu & Dewa & Sambu \\
\hline
\end{tabular}




\begin{tabular}{|c|c|c|c|}
\hline $\begin{array}{l}\text { Aksara } \\
\text { Suci }\end{array}$ & A : Pranawa "Ung" & $\begin{array}{l}\text { Aksara } \\
\text { Suci }\end{array}$ & Wa (wang) \\
\hline Fungsi & Pemelihara (sthiti) & Fungsi & $\begin{array}{l}\text { Kekuatan atmosfer dan } \\
\text { udara }\end{array}$ \\
\hline Warna & Hitam & Warna & Biru/ abu-abu \\
\hline Wahana & Garuda & Wahana & Wilmana \\
\hline Senjata & Cakra & Senjata & Tri Sula \\
\hline $\begin{array}{l}\text { Panca } \\
\text { Wara }\end{array}$ & Soma & $\begin{array}{l}\text { Panca } \\
\text { Wara }\end{array}$ & \\
\hline $\begin{array}{l}\text { Sapta } \\
\text { Wara }\end{array}$ & Dewi Sri & $\begin{array}{l}\text { Sapta } \\
\text { Wara }\end{array}$ & Sukra \\
\hline Sakti & & Sakti & Dewi Mahadewi \\
\hline Nada & Dung (ksung) & Nada & Ndung \\
\hline
\end{tabular}

\begin{tabular}{|l|l|}
\hline Arah & Tengah/Madya \\
\hline Urip & 8 \\
\hline Pura & Besakih \\
\hline Dewa & Ciwa \\
\hline $\begin{array}{l}\text { Aksara } \\
\text { Suci }\end{array}$ & Ing/Yang \\
\hline Fungsi & $\begin{array}{l}\text { Kekuatan Jiwa-jiwa } \\
\text { agung }\end{array}$ \\
\hline Warna & $\begin{array}{l}\text { Panca } \\
\text { Brumbun }\end{array}$ \\
\hline Wahana & Padma \\
\hline Senjata & Kliwon \\
\hline $\begin{array}{l}\text { Panca } \\
\text { Wara }\end{array}$ & Dong \\
\hline Nada
\end{tabular}

Dalam menciptakan komposisi Karawitan Bali, konsep tersebut banyak banyak memberikan refrensi atau sumber acuan dalam berkarya. Unsur simbol dari kekuatan yang ada pada masing-masing penjuru mata angin, menjadi pijakan dalam menuangkan ide dan gagasan dalam media ungkap. Pertama, unsur urip dari Pangider Bhuana. Unsur ini paling banyak menjadi dasar pola garap musikal dalam karya sang seniman. Kekuatan urip dari arah mata angin diolah menjadi pola hitungan ketukan, melodimelodi, ritme, menjadi sebuah kesatuan yang bermuara pada keharmosisan pola garap musikal. Kedua, kekuatan warna yang menduduki arah mata angin. Warna memiliki karakteristik tersendiri. Unsur ini, diimajinasikan kedalam sebuah komposisi dari pengimplementasian dari konsep-konsep warna yang ada. Misalkan, warna putih sebagai simbol dari kekuatan Dewa Iswara, diungkapkan melalui pola melodi atau musikal yang tenang, mengalun, lirih, dan enak didengar. Warna merah, disimbolkan sebagai kekuatan dari Dewa Brahma. Unsur tersebut diungkapkan lewat bahasa musikal yang tajam, dinamis, dan ritmis. Kuning sebagai simbol dari kekuatan dewa Mahadewa, memberikan simbol sejuk yang diungkapkan melalui bahasa musikal melalui melodi-melodi yang mengalir dalam tempo sedang. Warna hitam disimbolkan sebagai kekuatan dari dari Dewa Wisnu, diungkapkan dalam musikal dengan pola melodi yang agung dan berwibawa. Sedangkan perpaduan antara warna tersebut diungkapkan melalui sebuah garap musikal yang utuh, menjadi sebuah garapan kesatuan, baik secara melodi, 
dinamika, ritme, tempo, harmoni sebagai simbol kekuatan Dewa Ciwa yang menguasai daerah tengah. Ketiga, aksara suci yang ada di masing-masing Pangider Bhuana. Didalam pengolahan musikal, penentuan nada dasar atau (gongan/jatuhnya pukulan gong) biasanya diambil dari nada-nada yang ada pada penjuru arah mata angin yakni, nada dang yang ada di arah Timur, nada ding yang berada di arah Selatan, nada deng yang ada di arah Barat, nada dung yang ada di daerah Utara, dan nada dong yang ada di Tengah. Nada ini merupakan urutan nada-nada yang ada pada laras pelog lima nada yakni : 3 (ding), 4 (dong), 5 (deng), 7 (dung), 1 (dang). Sedangkan nada-nada yang lain yang ada di arah Tenggara, merupakan perpaduan antara nada dang dengan ding, menjadi (ndang). Arah Barat Daya, merupakan perpaduan antara nada ding dengan deng, menjadi 2 (nding). Arah Barat Laut merupakan perpaduan antara nada deng dengan dung, menjadi (ndeng). Arah Timur Laut, merupakan perpaduan antara nada dung dengan dang, menjadi 6 (ndung). Bila diurutkan nada-nada tersebut menjadi 1234 567 . Kekuatan nada dong terletak di tengahtengah.

\section{Beberapa Karya Seni yang bersumber dari Konsep Pangider Bhuana}

\section{Tawur.}

Tawur sebagai sebuah tema dalam garapan ini memberikan inspirasi dan dorongan emosional secara kreatif. Rangkaian proses upacara menjadi ide menarik untuk ditransformasikan ke dalam sebuah bentuk komposisi Karawitan. Dari hasil observasi, penata sendiri telah mengalami, melihat dan menyaksikan proses yang terjadi pada saat pergantiaan tahun baru caka. Dengan mengalami hal tersebut timbul ide untuk mewujudkan atau mengkemasnya ke dalam bentuk komposisi Karawitan. Setelah beberapa kali penata membaca sumber yang relevan dan pertimbangan-pertimbangan yang matang terkait dengan tema yang akan diangkat, maka timbul ide untuk menggunakan gamelan Babonangan sebagai media ungkap. Alasannya karena dalam salah satu sumber tertulis yang penata baca yakni Lontar Prakempa, disebutkan bahwa gamelan Babonangan merupakan gamelan yang memang diciptakan oleh Sang Bhuta Kala dan memang difungsikan untuk mengiringi upacara Bhuta Yadnya dan nama gendingnya adalah Ketug Bhumi.

Didalam pengolahan musikalnya, garapan ini mempergunakan ketukan-ketukan 5, 9, 7, 4, 8 (Urip Pangider Bhuana) sebagai simbol keseimbangan alam. Pola melodi juga dihiasi dengan aksara suci dari Pangider Bhuana yakni; sa, ba, ta, a, i, na, ma, ci, wa, ya. Karya komposisi ini disajikan dalam rangka Ujian Tugas Akhir Strata 1, ISI Denpasar, oleh I Nyoman Mariyana, tahun 2007.

\section{1. "Pendro Sebuah Karawitan Hibrid".}

Pendro adalah singkatan dari Pelog-

Selendro yang merupakan dua buah laras yang sering dipakai dalam gamelan Bali. Kedua laras ini digunakan pada masing-masing gamelan yakni, gamelan angklung yang berlaraskan selendro dan gamelan Gong Kebyar yang berlaraskan pelog. Perbedaan laras ini, oleh komposer mencoba digabungkan menjadi satu garapan musik kontemporer. Penggunaan pola hitungan dalam tempo dan melodi juga bersumber dari konsep Pangider Bhuana. Karya musik kontemporer ini diciptakan tahun 2004, oleh bapak I Wayan Arnawa, salah satu seniman karawitan asal Tunjuk, Tabanan.

\section{Tri Datu}

Adalah sebuah bentuk komposisi tabuh Baleganjur yang disajikan dalam acara Pesta Kesenian Bali yang ke-38, Tahun 2016, sebagai duta kabupaten Tabanan. Tri Datu adalah penggabungan tiga warna pokok (putih, merah, hitam). Komposisi ini menggunakan simbol warna dan urip yang diambil dari Pangider Bhuana, yakni ; Putih sebagai lambang Dewa Iswara, urip 5, bertempat di arah Timur. Merah sebagai lambang Dewa Brahma, urip 9, bertempat di Selatan, dan warna hitam, sebagai lambang dari Dewa Wisnu, urip 4, bertempat di Utara. Unsur-unsur dalam Pangider Bhuana ini, 
kemudian digarap oleh komposer "Yanik" (Agustana) dari Tabanan, menjadi sebuah bentuk komposisi musik Baleganjur yang dinamis, ritmis, melodis, sebagai satu kesatuan, diimbangi dengan pola gerak penabuh yang dibalut dengan kostum Tri Datu (merah, putih, hitam) menambah meriahnya suasa di atas pentas.

\section{KESIMPULAN}

Sesungguhnya alam telah memberikan banyak manfaat bagi setian insan yang hidup di bumi ini. Dalam menciptakan sebuah komposisi Karawitan banyak seniman mengambil ide yang bersumber dari alam. Banyak juga yang mengambil ide yang bersumber dari konsep-konsep Hindu, yang mengatur tatanan kehidupan. Pangider Bhuana adalah sebuah konsep yang mengatur keseimbangan alam Bhuana Agung dengan Bhuana Alit (manusia). Unsur-unsur yang terdapat pada konsep Pangider Bhuana, seperti, urip, warna, dewa, nada, aksara suci, menjadi refrensi sang seniman dalam mencipta. Kekuatan itu, memberikan warna dalam musikal garapnya.

Kiranya falsafah-falsafah dalam lontar Prakempa sebagai ilmu gamelan Bali sebagai identitas budaya lokal, perlu lebih ditanamkan sebagai pilar untuk memperkokoh jati diri kita. Hal tersebut dilakukan karena dengan pemahan segala sesuatu yang berhubungan dengan lontar Prakempa, maka kita dalam berkarya seni akan lebih terarah dan tidak bertentangan dengan empat unsur pokok dalam lontar Prakempa yakni Filsafat, Etika, Estetika dan Teknik Gegebug atau dengan kata lain, dengan agama hidup kita akan menjadi terarah, dengan teknologi kita akan menjadi lebih maju.

\section{DAFTAR PUSTAKA}

Alma M. Hawkins. 1990. Mencipta Lewat Tari (Creating Through Dance). Dialihbahaskan oleh Y. Sumandiyo Hadi. Yogyakarta : Institut Seni Indonesia Yogyakarta

Arnawa, I Made.2005. "Pendro Sebuah Karawitan Hibrid". dalam Bheri Jurnal
Ilmiah Musik Nusantara. Volume 4 no.1 September 2005. Denpasar : Jurusan Karawitan Institut Seni Indonesia Denpasar

Aryasa, I WM. 1984. Pengetahuan Karawitan Bali. Denpasar : Departemen Pendidikan dan Kebudayaan Direktorat Jendral Kebudayaan Proyek Pengembangan Kesenian Bali

Bandem, I Made. 1988. Prakempa Sebuah Lontar Gamelan Bali. Denpasar : Sekolah Tinggi Seni Indonesia Denpasar 1987. Ubit-Ubitan Sebuah Teknik Permainan Gamelan Bali. Denpasar : Ditjen Pendidikan Tinggi DEPDIKBUD

Dayuh Mah, Nyoman. 2003. "Makna Hari Raya Nyepi" dalam Warta Hindu Darma Berdasarkan Satyam, Siwam dan Sundaram. Denpasar : Parisada Hindu Dharma Indonesia Pusat

Djelantik, A. A. M. 1987. Pengantar Dasar Ilmu Estetika jilid I Estetika Instrumental Edisi ke-2. Denpasar : Proyek Pengembangan IKI Sub / Bagian Proyek Peningkatan/Pengembangan Akademi Seni Tari Indonesia Denpasar Indiani, Ni Made. 1997. "Konsepsi Tri Hita Karana". Vidya Wertta. Denpasar : Media Komunikasi Universitas Hindu Indonesia Denpasar : UNHI

Mardiwarsito, L. Kamus Jawa Kuna Indonesia. Nusa Indah : Ende Flores Warna, I Wayan. Dkk. 1990. Kamus BaliIndonesia. Dinas Pendidikan Dasar. Propinsi Dati I Bali 